\title{
RANCANG BANGUN APLIKASI PERKIRAAN PENJUALAN PADA CV MULA JAYA NOFINA MENGGUNAKAN ANALISA FORECASTING
}

\author{
Ranno Putra Chairandy ${ }^{1}$, Deddy Kusbianto P.A ${ }^{2}$, Banni Satria Andoko ${ }^{3}$ \\ Program Studi Teknik Informatika, Jurusan Teknik Elektro, Politeknik Negeri Malang \\ ranno.chairandy@gmail.com ${ }^{1}$,deddy_kusbianto@polinema.ac.id ${ }^{2}$, banniandoko@gmail.com $^{3}$
}

\begin{abstract}
Abstrak
CV Mula Jaya Nofina merupakan CV yang menyuplai barang kebutuhan perusahaan-perusahaan besar. Barang yang disediakan oleh CV Mula Jaya Nofina tidak terfokus pada satu jenis barang saja, melainkan meliputi seluruh jenis barang. Ada beberapa jenis barang yang pembeliannya terdeteksi dilakukan secara rutin setiap bulannya. Nilai penjualan barang tersebut tentunya mengalami kenaikan dan penurunan, baik yang signifikan maupun tidak. Dengan adanya data penjualan di tempo hari, maka pegawai dapat melakukan forecasting nominal penjualan berikutnya. Tujuan utama dibuatnya aplikasi ini adalah untuk membantu pegawai dalam melakukan forecasting, menggunakan Analisa Runtut Waktu (Time Series Analysis). Sedangkan metode yang digunakan adalah Metode Rata-rata Bergerak Sederhana (Simple Moving Average Method). Variabel yang dijadikan patokan hanya satu parameter untuk perhitungannya, sehingga dapat disebut Single Moving Average Method. Hasil dari aplikasi ini berupa informasi mengenai jumlah penjualan yang mungkin terjadi pada periode akan datang sehingga pegawai dapat mempersiapkan jumlah suatu barang sesuai dengan hasil forecasting tersebut. Namun hasil perhitungan pada aplikasi ini menghasilkan nilai kesalahan yang cukup besar, melebihi standar deviasinya. Sehingga dapat disimpulkan bahwa forecasting menggunakan Metode Single Moving Average ini kurang tepat apabila diterapkan pada pola data yang bersifat siklis.
\end{abstract}

Kata kunci : forecasting, penjualan, metode rata-rata bergerak sederhana.

\section{Pendahuluan}

Setidaknya ada tiga faktor dalam transaksi jual beli, yaitu penjual, pembeli, dan pastinya barang. Dengan tidak adanya satu saja dari ketiga faktor tersebut, maka dapat dipastikan kegiatan jual beli tidak akan ada. Dalam kasus ini, pihak penjual adalah CV Mula Jaya Nofina, dan beberapa pabrik sebagai pihak pembeli.

Dari kegiatan jual beli ini ada laporan yang bisa dihasilkan. Laporan transaksi yang biasanya dicatat manual dalam bentuk kertas, sangat menyulitkan pegawai dalam melakukan penyortiran data. Pegawai tersebut juga tidak akan mudah untuk menyimpulkan barang apa saja yang sering dibeli oleh suatu pabrik. Selain itu, pegawai akan sangat sulit untuk menghitung berapa pengeluaran dan pemasukan dari transaksi pembelian tersebut. Tentunya hal ini dapat dibantu oleh adanya sistem informasi manajemen yang disesuaikan dengan kebutuhan. Dengan adanya sistem informasi manajemen, seorang pegawai dapat melakukan pencarian dan pencatatan data barang secara digital dengan akurasi data yang baik dibandingkan pencarian dan pencatatan data secara manual.

CV Mula Jaya Nofina merupakan CV yang menyediakan jasa suplai barang umum maupun barang yang spesifik ke suatu pabrik atau perusahaan yang membutuhkan. Dari kegiatan jual beli ini ada laporan yang bisa dihasilkan. Pada awalnya, laporan ini berbentuk kertas. Namun dengan adanya sistem informasi ini, laporan telah dirubah ke dalam bentuk digital.

Mengenai barang yang terjual, ada beberapa barang yang dibeli oleh pabrik secara berkala di tiap minggu dan/atau bulan. Dari hal ini, akan lebih baik jika kita dapat memperkirakan berapa jumlah penjualan barang yang mungkin akan dibeli oleh pabrik tersebut, agar CV Mula Jaya Nofina dapat mengalokasikan dana untuk proses pembelian tersebut. Oleh karena itu dibutuhkan suatu alat bantu yang dapat membantu dan memaksimalkan kinerja perusahaan dalam forecasting nilai jual pada periode yang akan datang.

Permasalahan yang akan coba dipecahkan oleh sistem informasi ini adalah:

a. Bagaimana cara mengaplikasikan Metode Rata-rata Bergerak Sederhana (Simple Moving Average) ke dalam proses forecasting penjualan perusahaan.

b. Bagaimana cara menghitung Goodness of Fit dari forecasting tersebut. 


\section{Metode}

\subsection{Metode Pengumpulan Data}

Data yang diramal merupakan data penjualan dari CV Mula Jaya Nofina. Data telah terkumpul sepanjang lima tahun ke belakang. Barang yang terjual sangat banyak macamnya. Jika data suatu barang terlalu sedikit, maka forecasting tidak akan dapat dilakukan. Maka dari itu, barang telah digolongkan menjadi beberapa kategori, diantaranya adalah Akrilik, ATK (Alat Tulis Kantor), Cat, Cetakan, Pallet, dan lain-lain. Sehingga dalam pengaplikasiannya, pengguna dapat melakukan forecasting berdasarkan kategorinya saja, bukan terhadap satuan barang.

\subsection{Metode Forecasting Rata-rata Bergerak Sederhana (Simple Moving Average)}

Model perkiraan dengan Simple Moving Average Method ini menghasilkan perkiraan untuk periode berikutnya yang merupakan rata-rata dari beberapa periode sebelumnya. Angka rata-rata untuk prakiraan dihitung atas dasar periode peraata tertentu, misalnya perata 3 bulanan, 6 bulanan, atau periode tertentu lainnya.

Penentuan banyaknya periode sebagai perata memang masih menjadi persoalan utama. Semakin panjang waktu perata, makin halus hasil forecasting yang didapatkan. Akan tetapi bila terdapat komponen trend, maka titik trend tersebut akan berada di atas atau di bawah trend yang seharusnya. Jika waktu peratanya pendek, faktor random tidak terhaluskan secara sempurna, tetapi angka rata-rata dapat mengikuti atau mendekati angka trend.

\subsubsection{Single Moving Average}

Mempunyai dua sifat khusus:

a. Untuk membuat prakiraan, memerlukan data historis selama jangka waktu tertentu.

b. Semakin panjang jangka waktu perata, akan menghasilkan prakiraan yang semakin halus.

Rumus yang digunakan (Markridakis:2009):

$$
F_{t}=\frac{\mathrm{Y}_{t-1}+\mathrm{Y}_{t-2}+\cdots+\mathrm{Y}_{t-n}}{\mathrm{n}}
$$

\section{Keterangan:}

$\mathrm{F}_{\mathrm{t}}$ : forecasting untuk periode $\mathrm{t}$

$\mathrm{Y}$ : jumlah data pada periode sebelumnya

$\mathrm{n}$ : jumlah periode dalam rata-rata bergerak

Variabel $\mathrm{n}$ dapat diisi angka sesuai dengan keinginan dari pengguna aplikasi. Namun secara otomatis nilai awal yang diberikan adalah 3 (tiga).
Istilah Rata-rata Bergerak digunakan karena setiap muncul nilai observasi baru, nilai rata-rata baru dapat dihitung dengan membuang nilai observasi yang paling tua dan memasukkan nilai observasi atau data yang terbaru.

\subsection{Perhitungan Nilai Kesalahan}

Untuk mengetahui tingkat "ketepatan" metode tersebut, maka nilai kesalahan atau error dapat dihitung menggunakan metode Kesalahan Rerata / Mean Error (ME).

\subsubsection{Metode Kesalahan Rerata / Mean Error atau Standar Deviasi}

Nilai penyimpangan data penjualan di bulan ke-n dengan forecasting yang telah dilakukan sebelumnya, akan dihitung dan dilihat rata-ratanya. Nilainya cenderung mendekati nol, karena kesalahan positif (penyimpangan di atas nilai rata-rata) akan menutup kesalahan negatif (penyimpangan di bawah nilai rata-rata). Menurut Markridakis dalam bukunya yang berjudul "Metode dan Aplikasi Peramalan," rumus yang digunakan adalah:

$$
M E=\frac{\sum \mathrm{F}}{\mathrm{n}}
$$

Keterangan:

ME : rata-rata kesalahan / Mean Error

$\sum \mathrm{F}$ : jumlah kesalahan

$\mathrm{n} \quad$ : jumlah periode dalam rata-rata bergerak

\subsection{Perancangan}

\subsubsection{Analisa Permasalahan}

Pada tahap ini, dilakukan langkah-langkah untuk menganalisa permasalahan yang sedang terjadi. Dari hasil analisa tersebut, maka didapat laporan mengenai sumber permasalahan, akibat, dan juga solusi apa yang dibutuhkan.

\subsubsection{Analisa Kebutuhan}

Setelah apa yang menyebabkan permasalahan tersebut didapat, maka dibuatlah desain sistem yang bertujuan untuk memenuhi kebutuhan agar dapat menyelesaikan masalah tersebut. 


\subsection{Pemodelan Sistem}

\subsubsection{PDM (Physical Data Model)}

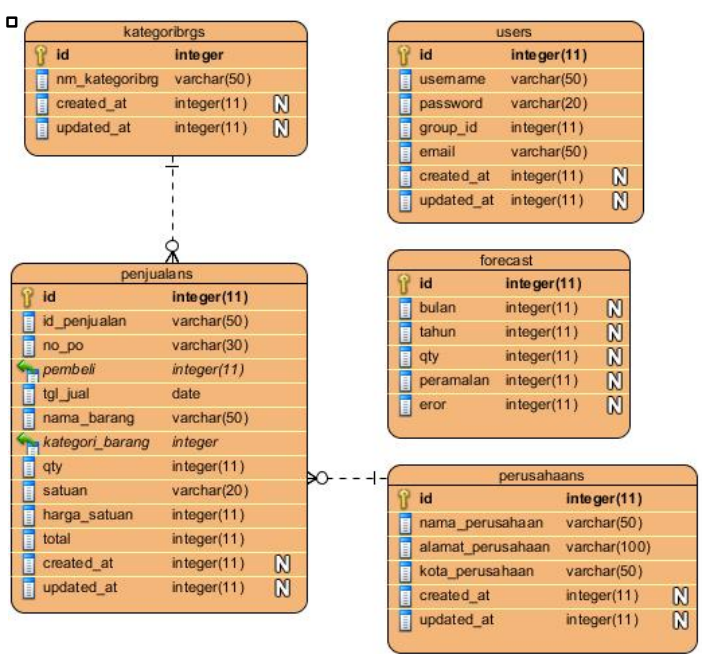

Gambar 2.1 Entity Relationship Diagram

\subsubsection{WBS}

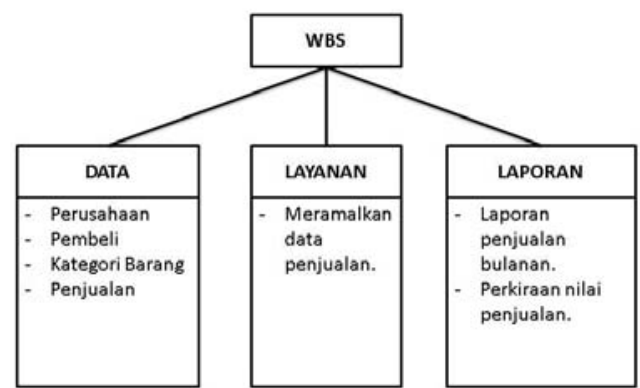

Gambar 2.2 Work Breakdown Structure

\subsubsection{Usecase}

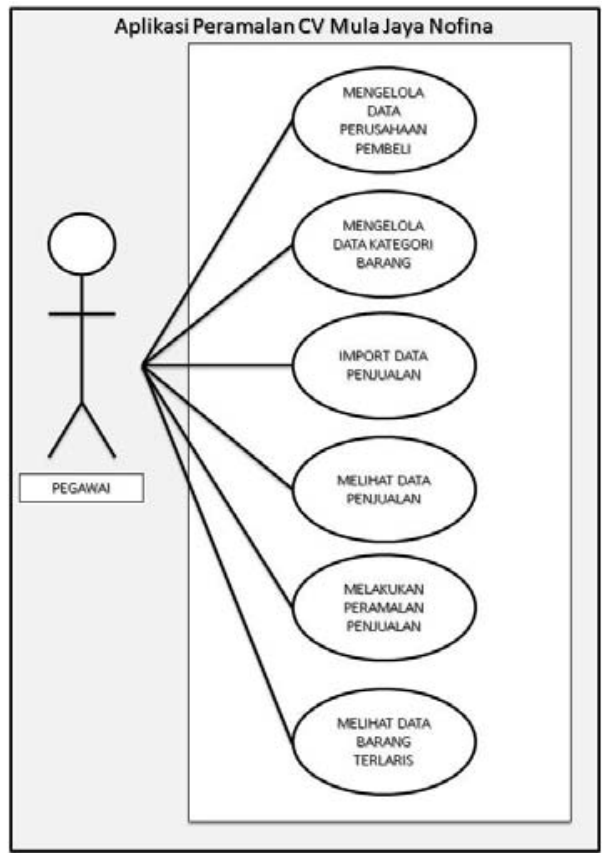

Gambar 2.3 Use Case Diagram

\subsubsection{Block Diagram}

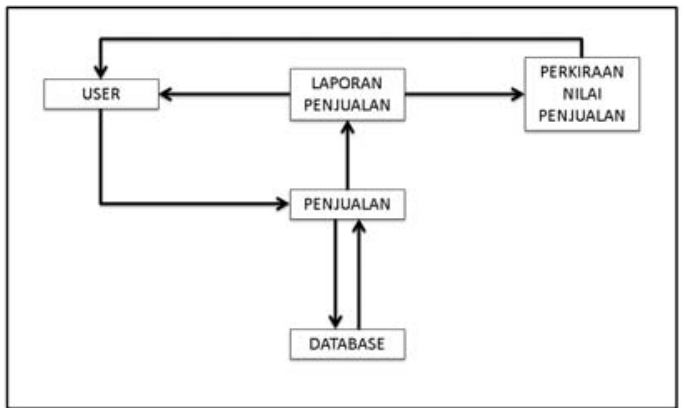

Gambar 2.4 Block Diagram

\subsubsection{Flowchart Garis Besar Sistem}

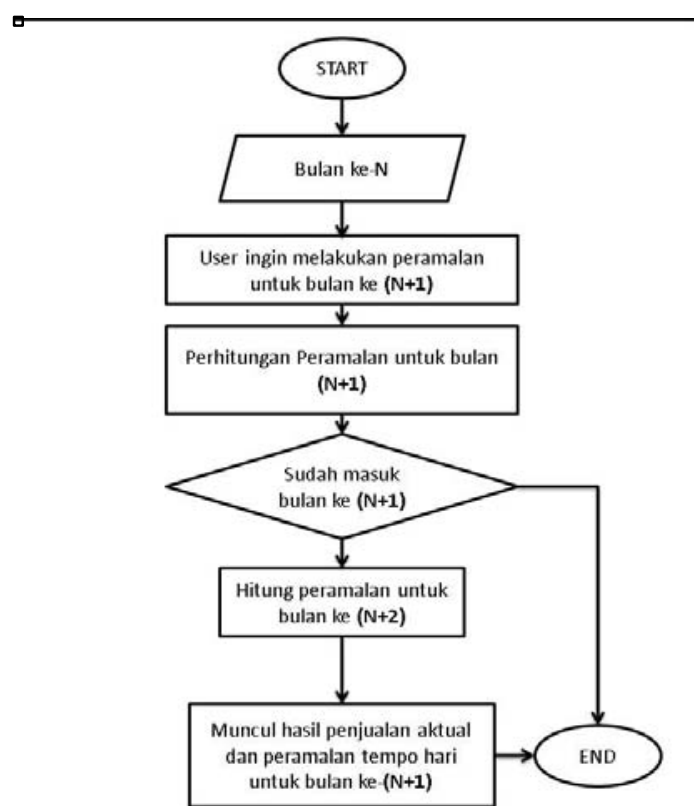

Gambar 2.5 Diagram Alir / Flowchart Garis Besar Sistem

\section{Hasil}

Aplikasi ini hanya membutuhkan tampilan pada satu sisi saja, yaitu pegawai. Tidak ada pengguna lain yang akan menggunakan aplikasi ini.

\subsection{Halaman Login 77 CV. MULA JAYA NOFINA}

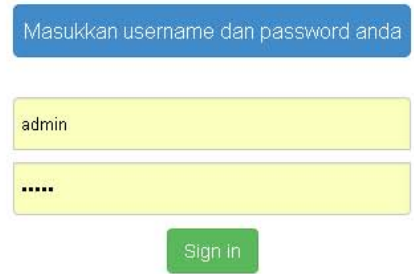

Gambar 3.1 Tampilan Halaman Login 


\subsection{Halaman Beranda}

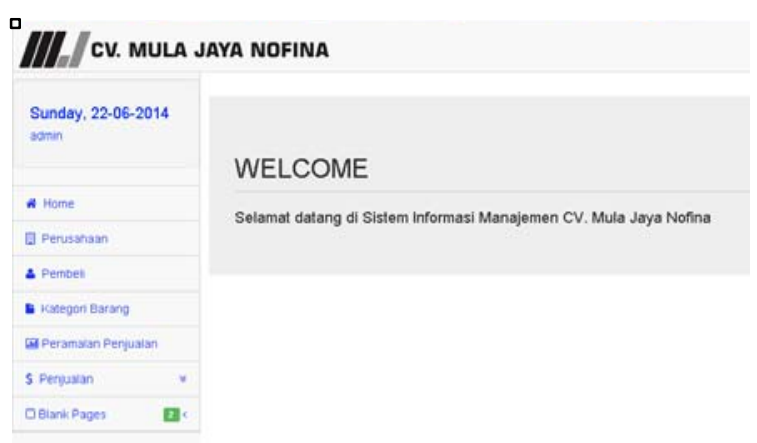

Gambar 3.2 Tampilan Halaman Home/Beranda

\subsection{Data Perusahaan}

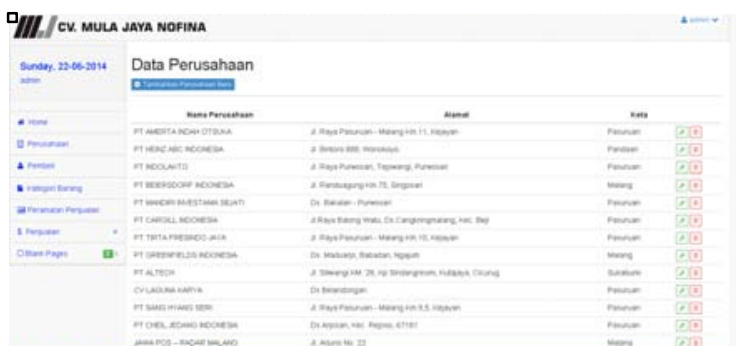

Gambar 3.3 Tampilan Data Perusahaan

\subsection{Data Penjualan}

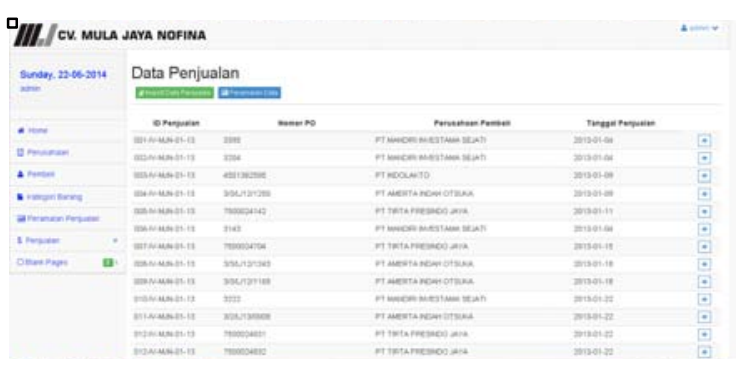

Gambar 3.4 Tampilan Data Penjualan

\section{Pembahasan}

\subsection{Data Penjualan}

Setelah proses pengumpulan datanya selesai, data yang terkumpul tiap tahunnya berkisar antara 500 sampai 800 baris data. Hal ini mengakibatkan dalam pengaksesan data penjualan, membutuhkan waktu yang sedikit lebih lambat. Karena kecepatan akses aplikasi pastinya berbanding lurus dengan jumlah data.

Namun hal ini dapat diantisipasi dengan menambahkan fitur paging. Jadinya, tidak semua data langsung ditampilkan, melainkan data sejumlah yang disetting sebelumnya.

Berdasarkan data yang telah dikumpulkan, penulis menarik kesimpulan bahwa data penjualan di CV Mula Jaya Nofina ini menunjukkan pola Siklis. Pola ini terjadi bila data dipengaruhi oleh fluktuasi ekonomi jangka panjang seperti yang berhubungan dengan siklus bisnis. Struktur datanya dapat digambarkan sebagai berikut.

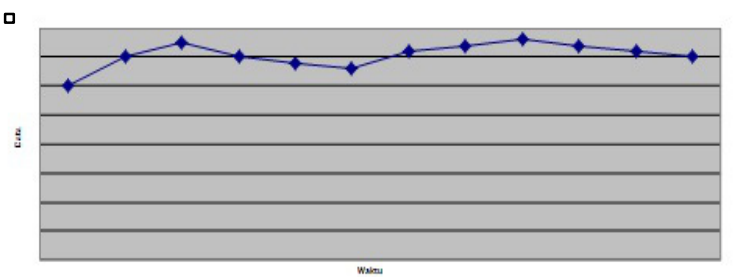

Gambar 4.1 Contoh Pola Data Siklis

\subsection{Penghitungan Forecasting}

Dalam melakukan forecasting penjualan, ada beberapa variabel yang harus diinputkan, yaitu:

a. Nama barang

b. Tahun penjualan

Jika kedua parameter telah terisi, maka data penjualan akan ditampilkan. Gambar di bawah menunjukkan pemilihan Nama Barang beserta Rerata perhitungan yang tersedia $(3,4,6$, dan 12 bulan).

Forecast Penjualan

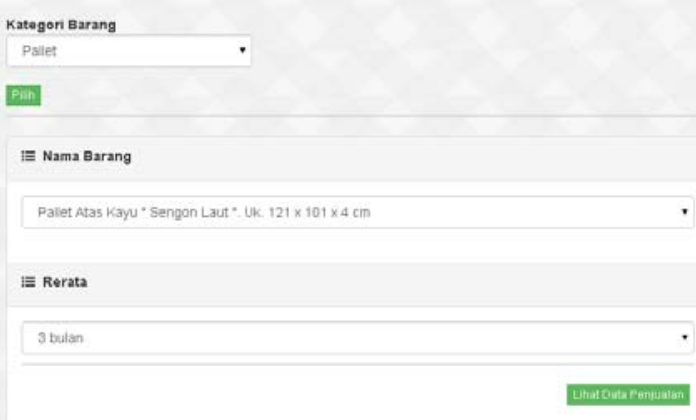

Gambar 4.2 Menampilkan Data Penjualan dengan Parameter Kategori Barang dan Tahun Penjualan.

Jika data penjualan tersebut tidak selalu ada di tiap bulannya, maka tetap akan dihitung menggunakan rumus yang telah disebutkan sebelumnya, dengan nilai nol pada bulan tersebut, bukan null.

Nantinya di sebelah kanan kolom Total_Penjualan, akan ada dua buah kolom lagi. Yang pertama adalah kolom untuk menampung perhitungan forecasting sesuai rumus, dan yang kedua adalah kolom untuk menghitung kesalahan dari hasil forecasting dengan data aktual pada bulan tersebut. 


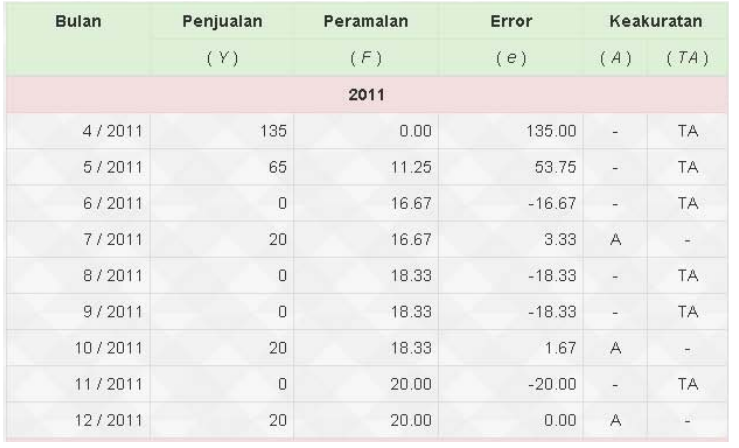

Gambar 4.3 Hasil Forecasting Penjualan Menggunakan Rata-rata 3 Bulan

\begin{tabular}{|c|c|}
\hline \multicolumn{2}{|c|}{ Perhitungan } \\
\hline Jumlah Data $(n)=$ & 41 \\
\hline $\begin{array}{l}\text { Jumlah Nilai Absolut Eror } \\
\qquad(\Sigma e)=\end{array}$ & 460.66 \\
\hline $\begin{array}{r}\text { Mean Absolute Deviation } \\
\text { ( } M A D) \\
\text { /Standar Deviasi }=\end{array}$ & 11.24 \\
\hline
\end{tabular}

Gambar 4.4 Hasil Penghitungan Nilai Standar Deviasi

Perhitungan forecasting ini disimpan ke dalam database secara temporary. Perhitungan ini hanya akan dilakukan jika pengguna aplikasi menginginkan saja. Jika tidak, maka aplikasi tidak akan menghitung. Hal ini dikarenakan apabila aplikasi secara terus-menerus melakukan forecasting, pada esok harinya akan terkumpul data forecasting tersebut, dan semakin lama akan menumpuk menjadi data yang tidak digunakan lagi. Karena perhitungan forecasting biasanya akan tidak dianggap berguna atau valueable lagi jika sudah terlewat masanya.

\subsection{Penghitungan Eror}

Pada bulan ke-n, pengguna melakukan forecasting untuk bulan $\mathrm{ke}-(\mathrm{n}+1)$. Setelah ditemukan hasil forecasting tersebut, jika pengguna aplikasi ingin menghitung nilai eror antara forecasting dan nilai aktual di bulan $(\mathrm{n}+1)$, maka user tinggal melakukan forecast lagi ketika sudah masuk ke bulan $(\mathrm{n}+1)$. Ketika sudah ada penjualan baru, maka akan nampak selisih dari nilai forecasting dengan data penjualan aktual. Namun nantinya tetap akan diberikan fitur untuk mencetak hasil forecasting.

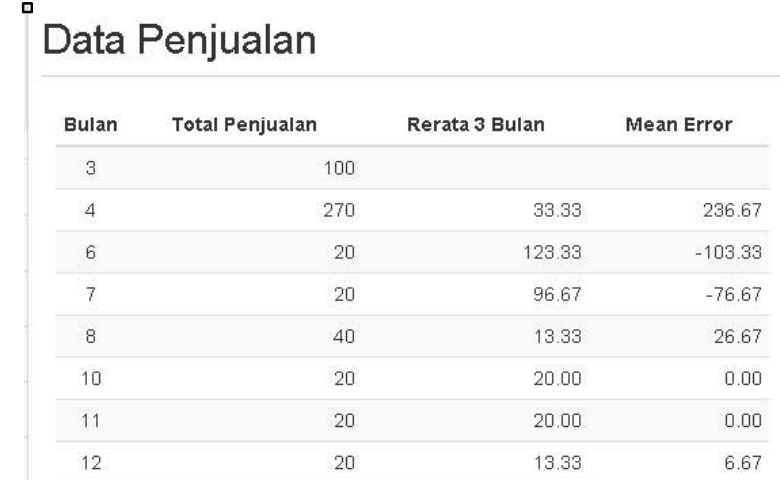

Gambar 4.5 Flowchart Penghitungan Forecasting dan Eror

Seperti yang telah dijelaskan sebelumnya, nilai Eror diambil dari hasil aktual yang dikurangi hasil forecasting di bulan $\mathrm{N}$.

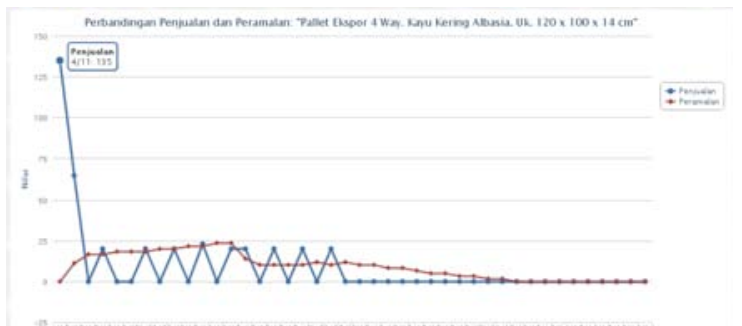

Gambar 4.6 Chart Atau Grafik yang Menunjukkan Nilai Forecasting dan Nilai Aktual Penjualan

\subsection{Data Penjualan Terlaris}

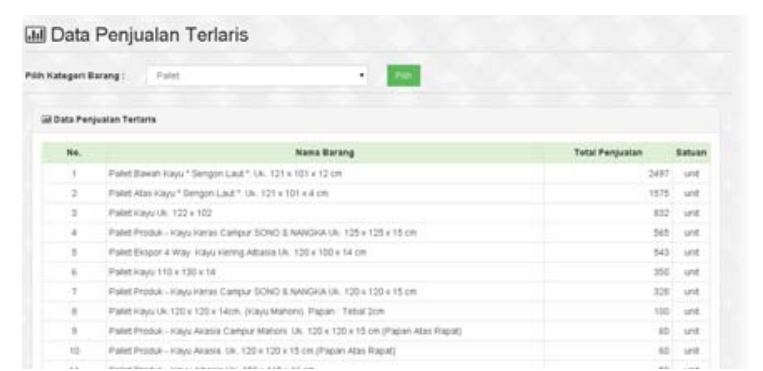

Gambar 4.7 Menampilkan Data Barang Terlaris untuk Kategori Tertentu

Fitur ini memungkinkan pengguna untuk melihat data barang terlaris berdasarkan kategori tertentu. Setelah kategori dipilih, maka akan ditampilkan nama barang beserta kuantitas dari barang tersebut. Barang yang ditampilkan teratas merupakan barang yang paling sering dibeli perusahaan.

\section{Kesimpulan dan Saran}

Setelah beberapa tahapan yang telah dilakukan, maka kesimpulan dari hasil aplikasi ini adalah:

1. Semakin besar rerata yang dipilih oleh pengguna, maka semakin kecil pula Mean Absolute Deviation atau nilai rata-rata kesalahannya. 
2. Nilai kesalahan yang ditampilkan sangat bervariasi. Hal ini disebabkan data penjualan yang ada juga bervariasi dari yang nilainya kecil hingga besar. Namun setelah dibandingkan dengan perhitungan secara manual, metode Single Moving Average telah berhasil diimplementasikan pada aplikasi ini. Hal ini telah dijelaskan pada sub bab 6.2 mengenai Perbangingan Nilai Peramalan dan Rata-rata Penjualan.

3. Konsekwensi dari nilai penjualan yang cenderung naik, akan menghasilkan nilai peramalan di bulan berikutnya yang juga naik. Namun apabila pola data penjualan yang tercatat naik dan turun tidak teratur, maka nilai peramalan juga bisa naik turun sesuai dengan perhitungan yang telah dijelaskan sebelumnya. Nilai penjualan yang tidak stabil juga akan membuat nilai peramalannya tidak stabil. Nilai peramalan yang mengikuti nilai penjualan, tidak lepas dari penerapan Metode Single Moving Average di aplikasi ini.

4. Berdasarkan sampel data penjualan dan hasil perhitungan peramalannya, terlihat bahwa perhitungan tersebut sering sekali menghasilkan nilai kesalahan yang cukup besar. Dari hal ini penulis menyimpulkan bahwa Metode Single Moving Average kurang tepat jika diimplementasikan pada pola data yang sangat bervariasi (naik

5. drastis dan turun drastis), dalam hal ini adalah CV Mula Jaya Nofina. Setelah dihimpun data penjualannya, diketahui bahwa pola data penjualan pada CV Mula Jaya Nofina bersifat horizontal.

6. Metode Single Moving Average lebih tepat apabila diterapkan terhadap data yang memiliki pola siklis. Untuk pola data siklis telah dijelaskan sebelumnya pada sub bab 2.3. Pola data siklis memang bisa naik dan turun. Namun hanya pada momen atau bulan tertentu saja.

Kemudian saran dari penulis untuk pengembangannya adalah:

1. Menilik dari hasil peramalan dan nilai kesalahannya, alangkah lebih baik apabila metode yang digunakan dirubah. Metode Single Moving Average dapat dirubah metodenya menjadi metode-metode yang masih tersedia, antara lain Metode Dekomposisi dan Metode Penghalusan / Pemulusan (Exponential Smoothing Method),

2. Pada aplikasi ini tidak ada format yang dapat dijadikan acuan dalam penamaan barang. Kedepannya sebaiknya diberikan format tertentu sehingga peramalan penjualan dapat dilakukan berdasarkan barang tertentu dengan tipe tertentu. Tidak berdasarkan kategori atau pengelompokan jenis barangnya. Hal ini akan memungkinkan pegawai untuk meramalkan nilai suatu barang secara lebih mendetail.

3. Dalam pencatatan penjualan, sebaiknya diberi satu kolom baru yang diisi dengan nama pegawai dari perusahaan pembeli yang terlibat dalam transaksi dengan nomor penjualan tersebut. Sehingga pegawai juga dapat mengetahui siapa saja rekanan yang terlibat dalam transaksi jual beli tersebut.

4. Dalam pembaruan data penjualan alangkah lebih baik bila disediakan fitur input melalui form yang disediakan. Sehingga tidak hanya mengandalkan import file berformat .csv saja. Hal ini dapat didukung dengan membuat function yang bertujuan agar nomor penjualan bisa didapatkan secara otomatis dari sistem.

\section{Daftar Rujukan}

[1] Arief, MR: Pemrograman Web Dinamis menggunakan PHP dan MySQL, Penerbit Andi, Yogyakarta, 2011.

[2] Darmawan, Deni \& Nur Fauzi, Kunkun: Sistem Informasi Manajemen, PT Remaja Rosdakarya, Bandung, 2013.

[3] Markridakis, Spyros dkk; Metode dan Aplikasi Peramalan, Penerbit Erlangga, Jakarta, 2009.

[4] Newbold, Paul dkk: Introductory Business Forecasting, South-Western Publishing Co., Ohio, 2000.

[5] Nugroho, Adi: Rekayasa Perangkat Lunak Berorientasi Objek Metode USDP (Unified Software Development Process), Penerbit Andi, Yogyakarta, 2010.

[6] S.A, Rosa: Modul Pembelajaran Rekayasa Perangkat Lunak. Bandung: Modula, 2011.

[7] Subagyo, Pangestu: Forecasting, Konsep dan Aplikasi, BPFE-YOGYAKARTA, Yogyakarta, 2002.

[8] Tweedie, Ross: Learning FuelPHP for Effective PHP Development, 2013).

[9] W., Soeparno: Analisis Forecasting dan Keputusan Manajemen (Teori dan Aplikasi Metode Analisis Kuantitatif, Penerbit Salemba Empat, Jakarta, 2009.

[10] Wilson, J. Holton dkk: Business Forecasting, The McGraw-Hill Companies, Inc., New York, 2002. 